\title{
Screening for novel quorum-sensing inhibitors to interfere with the formation of Pseudomonas aeruginosa biofilm
}

\author{
Xian Ding, ${ }^{1,2}$ Bo Yin, ${ }^{3}$ Li Qian, ${ }^{4}$ Zhirui Zeng, ${ }^{1}$ Zeliang Yang, ${ }^{1}$ Huixian Li, ${ }^{1}$ \\ Yongjun $\mathrm{Lu}^{1}$ and Shining $\mathrm{Zhou}^{1}$ \\ ${ }^{1}$ State Key Laboratory for Biocontrol, School of Life Sciences, Zhongshan (Sun Yat-sen) University, \\ Guangzhou 510275, PR China \\ ${ }^{2}$ South China Sea Fisheries Research Institute, Chinese Academy of Fishery Sciences, \\ Guangzhou 510300, PR China \\ ${ }^{3}$ LED, South China Sea Institute of Oceanology, Chinese Academy of Science, Guangzhou 510301 , \\ PR China \\ ${ }^{4}$ School of Chemistry and Chemical Engineering, Zhongshan (Sun Yat-sen) University, \\ Guangzhou 510275, PR China
}

Correspondence

Shining Zhou

Isszs|@mail.sysu.edu.cn

Received 9 July 2010

Accepted 15 August 2011
The objective of this study was to screen for novel quorum-sensing inhibitors (QSIs) from traditional Chinese medicines (TCMs) that inhibit bacterial biofilm formation. Six of 46 active components found in TCMs were identified as putative QSIs based on molecular docking studies. Of these, three compounds inhibited biofilm formation by Pseudomonas aeruginosa and Stenotrophomonas maltophilia at a concentration of $200 \mu \mathrm{M}$. A fourth compound (emodin) significantly inhibited biofilm formation at $20 \mu \mathrm{M}$ and induced proteolysis of the quorum-sensing signal receptor TraR in Escherichia coli at a concentration of 3-30 mM. Emodin also increased the activity of ampicillin against $P$. aeruginosa. Therefore, emodin might be suitable for development into an antivirulence and antibacterial agent.

\section{INTRODUCTION}

Pseudomonas aeruginosa, an opportunistic human pathogen, may cause acute infections in hospitalized patients, can be isolated from the environment, particularly from soil and water, and it regularly contaminates medical devices (Stover et al., 2000). It is also the predominant cause of chronic lung infection in cystic fibrosis patients (Frederiksen et al., 1997) and has recently been recognized as one of the main causes of chronic wound infections (Gjødsbøl et al., 2006). P. aeruginosa can infect patients by producing a wide range of virulence factors, the expression levels of which are tightly regulated. Key to this regulation is cell density-dependent cell-to-cell signalling, which is termed quorum sensing (QS) (Rumbaugh et al., 2000). As in many other bacteria, QS controls secretion of virulence factors (Mittal et al., 2006), biofilm formation (Waters et al., 2008) and the exchange of DNA (Fuqua \& Winans, $1996)$ in $P$. aeruginosa. The biofilm mode of growth is recognized as an important bacterial trait that is relevant to infections (Costerton et al., 1994). Many infections involve

Abbreviations: $\mathrm{AHL}, \mathrm{N}$-acylhomoserine lactone; 3-oxo-C8-HSL, N-(3oxo-octanoyl)-L-homoserine lactone; OS, quorum sensing; OSI, quorumsensing inhibitor; TCM, traditional Chinese medicine. the formation of bacterial biofilms, which are bacterial communities that settle and proliferate on surfaces and are covered by exopolymers (Lewis, 2007). Once established, biofilms are difficult to eradicate and become a source of secondary infection (Jones et al., 2009). Moreover, bacteria embedded in biofilms are more tolerant than planktonic cells of antibiotics (Donlan \& Costerton, 2002; Drenkard, 2003). The dose of antibiotics needed in this situation will often exceed the highest deliverable dose, which makes efficient treatment impossible.

QS, as a regulatory mechanism, enables bacteria to make collective decisions with respect to the expression of a specific set of genes that involve the production, release and subsequent detection of chemical signalling molecules, such as $\mathrm{N}$-acylhomoserine lactones (AHLs) that are commonly used by Gram-negative bacteria. When the concentration of AHLs reaches a certain threshold level, binding to a receptor molecule (for example, LuxR) is promoted and the activated LuxR-AHL complex forms dimers or polymers, which, in turn, act as transcriptional regulators of target genes in the QS regulon (Parsek \& Greenberg, 2000; Vannini et al., 2002). P. aeruginosa uses AHLs to coordinate the expression of a battery of virulence genes and induction of biofilm formation via a cascade of 
regulatory events (Passador et al., 1993), and so the QS system is involved in establishing infections as well as elevating tolerance to antibiotics (Drenkard, 2003).

The traditional approach for the treatment of infectious diseases is to kill or inhibit the growth of bacteria using antibiotics, which has selected for resistance to these drugs, and this has particularly been the case in P. aeruginosa. In response to the rise of antibiotic resistance, the continued development of new drugs and the judicious use of our current arsenal of antibiotics is required (Bergstrom et al., 2004). In this context, the development and use of QSinhibition-based drugs to attenuate bacterial pathogenicity is attractive (Boyen et al., 2009; Jones et al., 2009). Indeed, possibly because of their anti-biofilm effects, some quorum-sensing inhibitors (QSIs) like patulin and garlic extracts have even been found to make $P$. aeruginosa more susceptible to antibiotics, for example, tobramycin (Hentzer et al., 2003; Rasmussen et al., 2005a, b).

Like all plants, traditional Chinese medicinal herbs grow in an environment that has high bacterial density and so they have co-existed with QS bacteria during their evolution. Accordingly, the herbs may have evolved protective mechanisms against bacterial infections, and may even produce QSIs, which reduce the pathogenic capability of bacteria (Zhu et al., 1998). Components of some traditional Chinese medicines (TCMs), derived from these herbs, have been identified to be effective in the treatment of various inflammatory and infectious diseases such as gastritis, stomatitis and pneumonia (Ma et al., 2005). Thus, it was considered interesting to screen compounds from known TCMs to test whether they have QSI activity.

The discovery of inhibitors for a target protein can be greatly facilitated by using computer-aided drug design. In particular, virtual database screening approaches offer the potential to identify novel chemical entities with a high probability of binding to a target protein (Furci et al., 2007). The 3D structures of transcriptional regulators from Agrobacterium tumefaciens, Escherichia coli and P. aeruginosa involved in QS have been elucidated (Vannini et al., 2002; Yao et al., 2006; Bottomley et al., 2007). On the basis of the TraR crystal structure from the plant-associated bacterium A. tumefaciens, mutational analyses indicated that TraR is directly involved in the transcriptional activation in response to QS (Vannini et al. 2002). As an autoinducer-dependent transcriptional activator of plasmid conjugal transfer genes, TraR positively regulates interbacterial conjugal transfer of the Ti plasmid (Zhu \& Winans, 2001). The complex of TraR with the QS ligand $\mathrm{N}$-(3-oxo-octanoyl)-homoserine lactone binds to promoter elements, called tra boxes, upstream of at least five different tra operons on the Ti plasmid and activates gene expression. A similar protein in $P$. aeruginosa is LasR, which controls the expression of virulence and biofilmassociated genes. The amino acid residues in the LasR and TraR active sites show significant identity $(70 \%)$ and the $3 \mathrm{D}$ model of the LasR active site closely resembles the X-ray structure of the TraR active site (Müh et al. 2006). Thus, inhibitors of TraR may have evolved in plants to combat the plant pathogen A. tumefaciens, but they may also inhibit LasR in the human pathogen $P$. aeruginosa. Accordingly, our approach was to first identify putative inhibitors of A. tumefaciens TraR based on structure analysis in combination with computer-aided drug design and biological assays, and then to test any potential QSIs for their ability to inhibit biofilm formation and antimicrobial drug sensitivity.

\section{METHODS}

Compound preparation. All the compounds (purity $\geqslant 98 \%$ ) used in this study were purchased from the Guangdong Institute for Drug Control (Guangzhou, China) and dissolved in DMSO. The QS signal molecule $\mathrm{N}$-(3-oxo-octanoyl)-L-homoserine lactone (3-oxo-C8-HSL, $\mathrm{AHL}$ ) was purchased from Sigma. Information on the six active components extracted from TCMs is listed in Table 1.

Ligand docking. The $3 \mathrm{D}$ structure of the A. tumefaciens QS transcriptional activator protein TraR, obtained from the Protein Data Bank (PDB ID code $1 \mathrm{H} 0 \mathrm{M}$ ), was used in the DOCK program. Only chain A was used for the model; the other chains (B, C, D, E, F, $\mathrm{G})$ and all the water molecules were removed. In the DOCK package, the binding pocket was described by spheres. Each sphere touched the molecular surface at two points and had its radius along the surface of one of the points. The spheres were generated by the program SPHGEN, which is distributed as an accessory of DOCK. To define the ligand-

Table 1. Compounds extracted from TCMs

\begin{tabular}{|c|c|c|c|c|}
\hline $\begin{array}{l}\text { Compound } \\
\text { number }\end{array}$ & Compound name & $\begin{array}{l}\text { Molecular mass } \\
\text { (Da) }\end{array}$ & TCM & $\begin{array}{l}\text { Docking score } \\
\left(\text { kcal mol}^{-1}\right)\end{array}$ \\
\hline & 3-Oxо-C8-HSL & & & -46.20 \\
\hline $\mathrm{C} 1$ & Rhein & 284.21 & Rheum palmatum L. & -7.78 \\
\hline $\mathrm{C} 2$ & Chrysophanol & 254.23 & Rheum officinale Baill. & -2.96 \\
\hline $\mathrm{C} 3$ & Nodakenetin & 408.40 & Peucedanum decursivum (Miq). Maxim & 10.96 \\
\hline $\mathrm{C} 4$ & Shikonin & 288.31 & Lithospermum erythrorhizon Sieb. & 6.08 \\
\hline C5 & Emodin & 270.23 & Rheum palmatum L. & -15.46 \\
\hline C6 & Fraxin & 370.31 & Fraxinus chinensis Roxb. & -20.16 \\
\hline Control & Halogenated furanone 30 & & & -28.94 \\
\hline
\end{tabular}


binding pocket in chain A of TraR, 3-oxo-C8-HSL, the autoinducer of TraR, was used as a ligand to select spheres. The spheres within $10 \AA$ of the ligand were selected. The sphere-selector module was used for sphere selection.

On the basis of the reported application of TCMs for the treatment of diseases, 46 compounds from these TCMs were selected to construct a database for screening potential novel TraR (and so QS) inhibitors. Then, the 46 compounds and halogenated furanone C30 (as a known QS inhibitor control) were rigidly docked into the TraR binding pocket to see whether they might competitively inhibit QS ligand binding. The box size was set at $6 \AA$, the grid space was $0.3 \AA$ and the energy cut-off distance was $9999 \AA$ A. Maximal orientations were set at 30000 . Default settings were used in docking. Before docking, the SYBYL program-package (SYBYL 6.9; Tripos Associates) was used to add hydrogen atoms and charges to the protein. All of the hydrogen atoms of the protein were added and refined in the presence of explicit solvent with a progressive energy-minimization protocol using AMBER7 FF99 force field. The termination gradient was $0.01 \mathrm{kcal}$ $\mathrm{mol}^{-1}$ and the maximal iteration was 1000 (SYBYL 6.9; Tripos Associates). Docking studies were performed with the DOCK 5.3.0 program (Meng et al., 1993).

Bacterial strains and culture conditions. $P$. aeruginosa PAO1 was routinely cultured in Luria-Bertani (LB) medium at $37{ }^{\circ} \mathrm{C}$ with 160 r.p.m. agitation in a shaking incubator. Medium was solidified with $1.2 \%$ agar when required. Stenotrophomonas maltophilia GIMT1.118 was cultured in medium (peptone $2.5 \mathrm{~g}$, beef extract $1.5 \mathrm{~g}, \mathrm{NaCl} 2.5 \mathrm{~g}$, agar $10 \mathrm{~g}, \mathrm{ddH}_{2} \mathrm{O} 500 \mathrm{ml}, \mathrm{pH} 7.2$ ) at $37{ }^{\circ} \mathrm{C}$ with 160 r.p.m. agitation in a shaking incubator. The traR gene (encoding TraR) was amplified from the plasmid pCF218 of A. tumefaciens WCF47(pCF372/pCF218) with primers TrarF (5'-CGCGGATCCCATGCAGCACTGGCTG- $3^{\prime}$ ) and TrarR (5'-CCGGAATTCTCAGATGAGTTTCCGC-3'). After being further digested with BamHI and EcoRI, the traR gene was cloned into the vector pET-17b (Novagen). The cloned plasmid (pETtrar) was electroporated into E. coli strain BL21(DE3) and the traR gene was expressed according to the manufacturer's instructions.

Assay of $\boldsymbol{P}$. aeruginosa growth. Antibacterial activity was tested by paper disc diffusion assay. P. aeruginosa was incubated in LB, $100 \mu \mathrm{l}$ of this culture $\left(\sim 10^{5}\right.$ c.f.u. $\left.\mathrm{ml}^{-1}\right)$ was spread onto an LB plate and three filter paper discs ( $8 \mathrm{~mm}$ in diameter) were placed on the plate. Different solutions, including $20 \mu \mathrm{l}$ test compound $(0.2,2,20$, $200 \mathrm{mM}$ ) plus $2 \mu \mathrm{l}$ ampicillin $\left(1.2 \mathrm{mg} \mathrm{ml}^{-1}\right), 20 \mu \mathrm{l}$ DMSO plus $2 \mu \mathrm{l}$ ampicillin $\left(1.2 \mathrm{mg} \mathrm{ml}^{-1}\right)$ and $20 \mu \mathrm{l}$ test compound $(0.2,2,20$, $200 \mathrm{mM}$ ) plus $2 \mu \mathrm{l}$ sterile water, were loaded onto the discs, respectively. The plate was cultured at $37{ }^{\circ} \mathrm{C}$ for $24 \mathrm{~h}$ and growth inhibition zones were measured (Choo et al., 2006).

Assay of biofilm formation by $\boldsymbol{P}$. aeruginosa and S. maltophilia. The biofilm assay was performed by the method described previously with further modification (You et al., 2007). Briefly, $1 \mathrm{ml}$ $P$. aeruginosa or S. maltophilia cells, which were cultured overnight and diluted to an $\mathrm{OD}_{600}$ of 1.0 , were mixed with $200 \mu \mathrm{M}$ of the different test compounds made up in $1 \%(\mathrm{v} / \mathrm{v})$ glycerol in $2 \mathrm{ml}$ microfuge tubes that were incubated at $37{ }^{\circ} \mathrm{C}$ for 3 days without shaking. The liquid in each tube was then removed and the bacteria adhering to the sides of the tubes were washed with sterile distilled water three times and air-dried. The remaining biofilm was stained with $1 \mathrm{ml} 0.5 \%(\mathrm{w} / \mathrm{v})$ crystal violet solution for $20 \mathrm{~min}$ and the excess dye in tubes was removed by washing with sterile distilled water three times. The quantitative analysis of biofilm was measured by adding $1 \mathrm{ml} 95 \%(\mathrm{v} / \mathrm{v})$ ethanol into the tube and waiting for $15 \mathrm{~min}$. Then, the $A_{570} \mathrm{~nm}$ of dissolved crystal violet was determined. To view biofilm formation under a microscope, cover glasses were put into $50 \mathrm{ml}$ conical flasks containing bacteria, in the presence or absence of test compounds $(200 \mu \mathrm{M})$, and incubated at $37{ }^{\circ} \mathrm{C}$ for 3 days without shaking. The cover glasses were recovered, washed gently with sterile distilled water, Gram stained, and examined under a microscope.

Assay of TraR degradation in $\boldsymbol{E}$. coli. The assay of TraR degradation in E. coli was performed by the method described previously with further modification (Zeng et al., 2008). E. coli BL21(DE3)(pETtrar) was incubated in LB broth at $37{ }^{\circ} \mathrm{C}$ with shaking until the $\mathrm{OD}_{600}$ of cells reached 0.3 . Then, $400 \mu \mathrm{M}$ isopropyl$\beta$-D-thiogalactoside was added, followed by further incubation at $37{ }^{\circ} \mathrm{C}$ for $4 \mathrm{~h}$. Subsequently, $1.5 \mathrm{ml}$ cultures were harvested by centrifugation $(10000 \mathrm{~g})$ at $4{ }^{\circ} \mathrm{C}$ for $2 \mathrm{~min}$. The cells were washed three times with an equal volume of sterile distilled water. The cells were resuspended in $50 \mu \mathrm{l}$ sterile distilled water containing $100 \mu \mathrm{g}$ ampicillin $\mathrm{ml}^{-1}$ and $100 \mu \mathrm{g}$ chloramphenicol $\mathrm{ml}^{-1}$ together with different test compounds (up to $30 \mathrm{mM}$ ), DMSO vehicle $(4 \%$, v/v) or AHL $\left(10 \mathrm{mg} \mathrm{ml}^{-1}\right)$, and incubated at $30{ }^{\circ} \mathrm{C}$ for up to $4 \mathrm{~h}$. Protein extracts were then produced from these cells, which were examined by SDS-PAGE.

\section{RESULTS}

\section{Screening for TCM compounds with potential anti-QS activity}

The DOCK 5.3.0 program was applied to screen for putative novel QS inhibitors of A. tumefaciens TraR from the database of compounds found in TCMs constructed by us. The results suggested that 9 compounds from the 46 candidates might be potential inhibitors of the QS system; i.e. they might potentially bind to the TraR protein and inhibit binding of the QS ligand, the AHL. In this study, six of these compounds with different docking scores were further selected for bioassay (Table 1). The predicted orientation of the potential QSI, compound 5 (emodin), bound to TraR was generated using the Chimera program (Pettersen et al., 2004) (Fig. 1). The interactions between compound 5, the halogenated furanone C30 (a known QSI) and TraR are depicted in Fig. 2.

\section{Assay of $\boldsymbol{P}$. aeruginosa growth}

The paper disc diffusion assay was performed to determine the antibacterial activity of compound 5 (emodin) against $P$. aeruginosa. An inhibition zone of $10.5 \mathrm{~mm}$ in diameter (including the paper disc diameter of $8 \mathrm{~mm}$ ) was observed on the discs containing ampicillin $\left(1.2 \mathrm{mg} \mathrm{ml}^{-1}\right)$, and an inhibition zone of $9.8 \mathrm{~mm}$ was observed on the discs containing compound 5 alone at a concentration of $200 \mathrm{mM}$. No inhibition zone was noted on the discs at a concentration of $0.2,2$ and $20 \mathrm{mM}$. However, inhibition zones of $10.8,11.4,12.8$ and $14.2 \mathrm{~mm}$ in diameter (including the paper disc diameter of $8 \mathrm{~mm}$ ) were observed on the discs containing both ampicillin $\left(1.2 \mathrm{mg} \mathrm{ml}^{-1}\right)$ and different concentration of compound $5(0.2,2,20$ and $200 \mathrm{mM})$.

The diameter of the inhibition zones was bigger in the presence of both compound 5 and ampicillin than in the presence of ampicillin alone. The results showed that whilst 


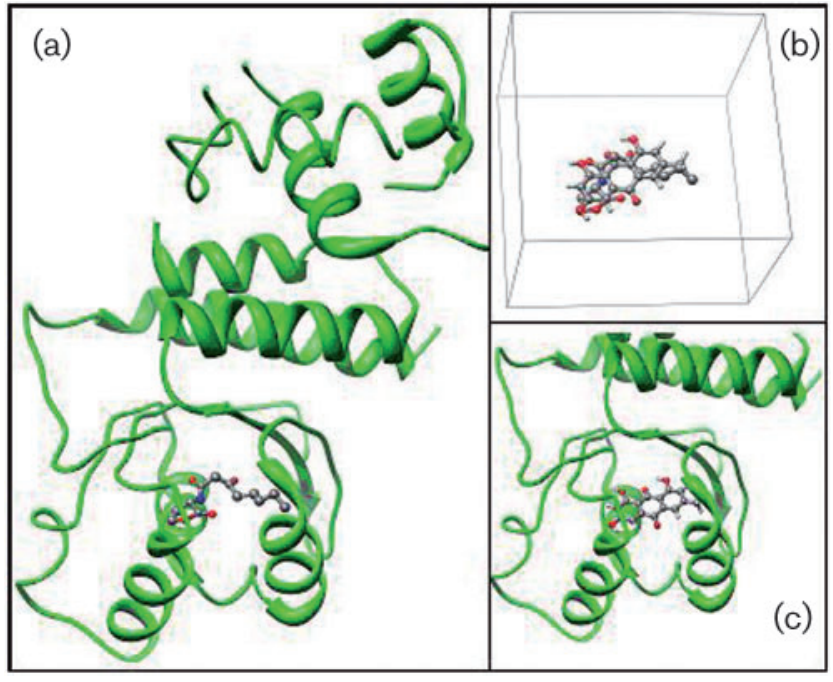

Fig. 1. (a) Map of the TraR receptor and the AHL OS ligand crystal structure. (b) Superposition of OS ligand and emodin. (c) Schematic presentation of the putative interaction between TraR and emodin.

emodin had little direct effect on the growth of $P$. aeruginosa a concentration of $0.2,2$ and $20 \mathrm{mM}$, and only a small activity against $P$. aeruginosa at $200 \mathrm{mM}$, emodin appeared to make $P$. aeruginosa more susceptible to ampicillin, an antibiotic to which $P$. aeruginosa is resistant.

\section{Effect of putative QSI compounds on biofilm formation of $P$. aeruginosa and $S$. maltophilia}

The results showed that compounds 2, 3, 4 and 5 could inhibit biofilm formation of $P$. aeruginosa and S. maltophilia. Of the four compounds, compound 5 (emodin) showed the most potent inhibitory activity (Fig. 3a). Further assays for the effect of compound 5 on biofilm formation of $P$. aeruginosa and S. maltophilia were carried out at different concentrations of compound 5 . The results indicated that compound 5 at $20 \mu \mathrm{M}$ could significantly inhibit biofilm formation ( $P<0.05$; Fig. 3b). Almost all of the $P$. aeruginosa and $S$. maltophilia cells incubated with compound 5 $(200 \mu \mathrm{M})$ detached and dispersed from the glass surface. In contrast, the control cells adhered to the glass surface, continued to proliferate, and also congregated together (Fig. 3c, d).

\section{Effect of putative QSI compounds on the degradation of TraR protein in vivo}

The intensity of the SDS-PAGE band was related to the concentration of the corresponding protein expressed in $E$. coli. The results showed that the concentration of TraR protein expressed in E. coli BL21(DE3)(pETtrar) decreased after being treated with compound 5 for $4 \mathrm{~h}$ (Fig. $4 \mathrm{a}$ ). Further studies were performed to examine the effect of different concentrations of compound 5 on the degradation of TraR (Fig. 4b). TraR concentration decreased with increased concentration of compound 5. When the concentration of compound 5 reached $30 \mathrm{mM}$, the concentration of TraR decreased rapidly within $0.5 \mathrm{~h}$. The effect of AHL on the degradation of TraR was also monitored. The results showed that the degradation of TraR was inhibited in the presence of AHL (Fig. 4c).

\section{DISCUSSION}

Inhibition of the bacterial QS system, rather than a bactericidal or bacteriostatic strategy, might be applied in many fields such as medicine, agriculture and food technology. This approach is very attractive because it is not directly involved in the inhibition of bacterial growth and does not impose harsh selective pressure for the development of resistance. Accordingly, there is a particular interest in finding new chemical entities that inhibit bacterial QS (Zeng et al., 2008; Ganin et al., 2009). A number of virtual screening techniques have been developed and have become an integral part of drug discovery, and are available in the literature to identify potent drug leads. In this study, such techniques have been
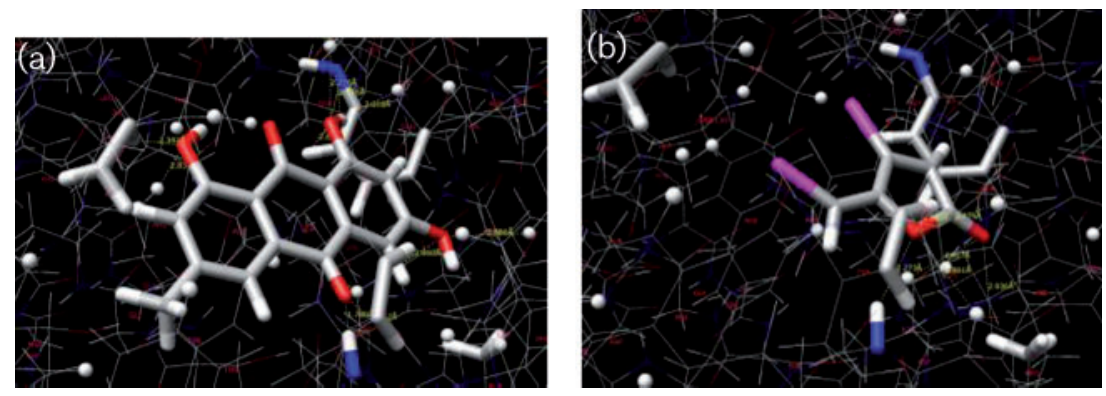

Fig. 2. Possible mode of binding of emodin and halogenated furanone $\mathrm{C} 30$ to TraR. (a) Interaction between TraR and emodin; (b) interaction between TraR and the known QSI halogenated furanone C30. The energy score consists of van der Waals and electrostatic components with the van der Waals predominant. 
(a)
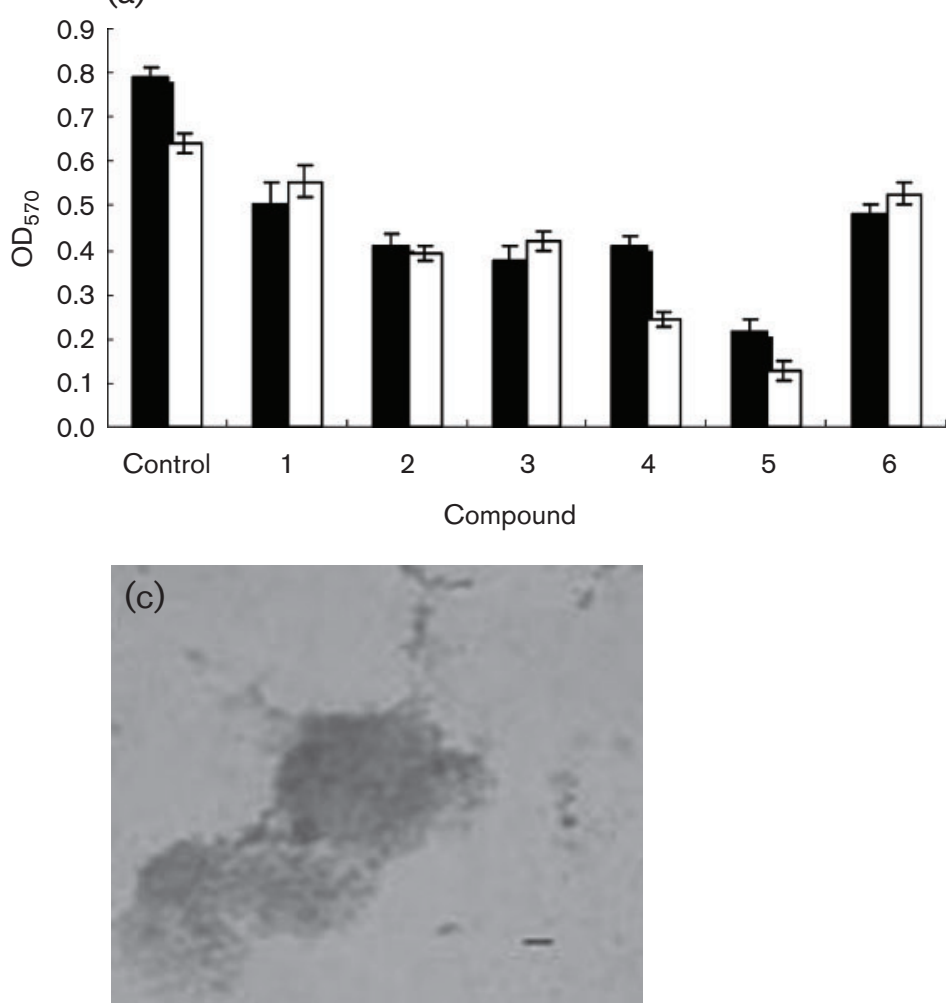

(b)
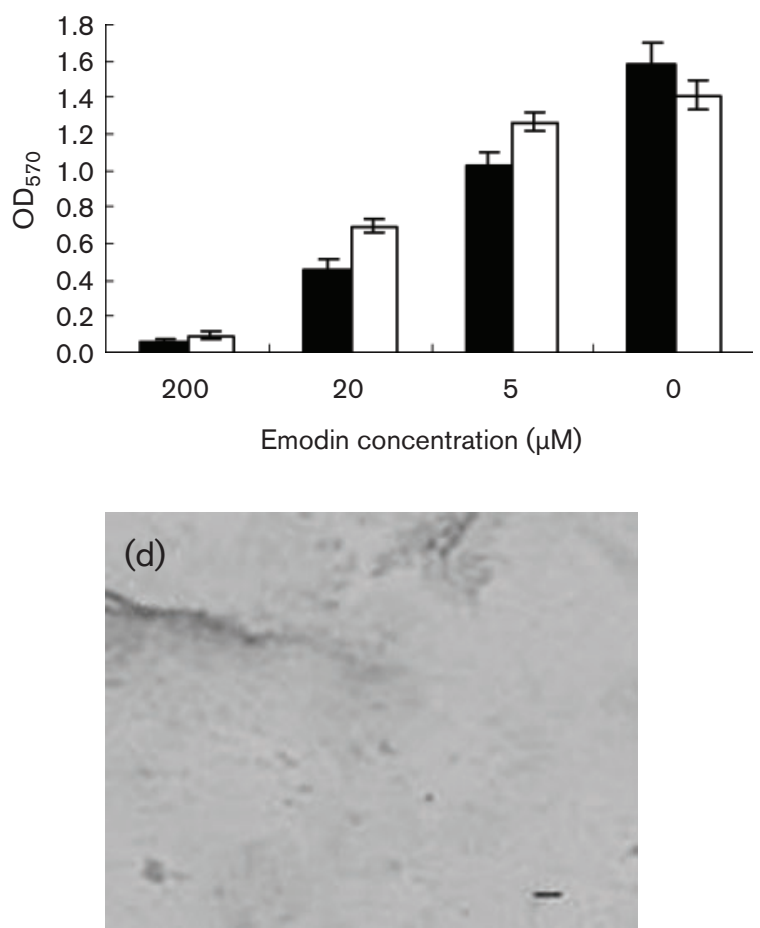

Fig. 3. Effect of different putative QSI compounds on biofilm formation of $P$. aeruginosa and S. maltophilia. (a) Treatment of $P$. aeruginosa (white bars) and S. maltophilia (black bars) with various compounds at $200 \mu \mathrm{M}$; (b) concentration-dependent effect of emodin (0-200 $\mu \mathrm{M})$ on biofilm formation of $P$. aeruginosa (white bars) and $S$. maltophilia (black bars); (c) micrograph of a $P$. aeruginosa biofilm; (d) micrograph of a $P$. aeruginosa biofilm following treatment with $200 \mu \mathrm{M}$ emodin. Bar, $10 \mu \mathrm{m}$.

applied to explore the effects of novel QS inhibitors extracted from TCMs on the inhibition of bacterial QS.

To date, the only known anti-QS compounds of nonbacterial origin are halogenated furanones from the red alga Delisea pulchra (Manefield et al., 1999). Anti-QS activity has also been noted in a number of traditional medicinal plants (Adonizio et al., 2006). Rhubarb (named Dahuang in Chinese), a medicinal plant, displays diverse pharmacological activities such as bacteriostatic, antiviral, antifungal and antitumour activities (Huang \& Zhen, 2001; Kim et al., 2004; Basu et al., 2005; Huang et al., 2005). Emodin, one of the free anthraquinone compounds extracted from rhubarb, is the major active constituent (Ma et al., 2008) that inhibits the expression of the tumour necrosis factor alpha (TNF- $\alpha$ ) gene (Chen et al., 2008) and tumour metastasis in vitro and in vivo (Kwak et al., 2006). It also promotes the apoptosis of human breast cancer BCap-37 cells (Huang et al., 2008). Some studies have also reported the effect of emodin on cell death in human prostate, lung, liver, cervical and blood cancer cells (Cha et al., 2005; Su et al., 2005; Jing et al., 2006; Fu et al., 2007; Muto et al., 2007). In this study, compound 5 (emodin) and ampicillin acted jointly against $P$. aeruginosa more effectively than either of them did alone, suggesting that compound 5 enhanced the activity of ampicillin against $P$. aeruginosa. The results were similar to the marked synergies between the compounds extracted from TCMs and antibiotics reported by Fujita et al. (2005) and Chang et al. (2007).

It has been well documented that biofilm growth and formation is a severe problem in medicine and industry (Costerton et al., 1995). The strategy to interrupt the QS system has been increasingly regarded as an important method to control the formation and growth of biofilm (Lynch et al., 2002). A QS-deficient biofilm of P. aeruginosa was almost entirely eliminated with antibiotics compared with the wild-type biofilm, in which only cells in the top layer were killed (Bjarnsholt et al., 2005). Shih \& Huang (2002) obtained similar results by comparing wild-type biofilm and QS-deficient biofilm treated with kanamycin. In this study, compound 5 (emodin) inhibited the adhesion of $P$. aeruginosa to a glass surface and biofilm formation (Fig. 3). The results were consistent with the findings of Rasmussen \& Givskov (2006). It is likely that compound 5 (emodin) penetrated into the biofilm and interfered with bacterial intercellular communications, by which the QS system of $P$. aeruginosa was disturbed and repressed. Moreover, previous studies have found that 


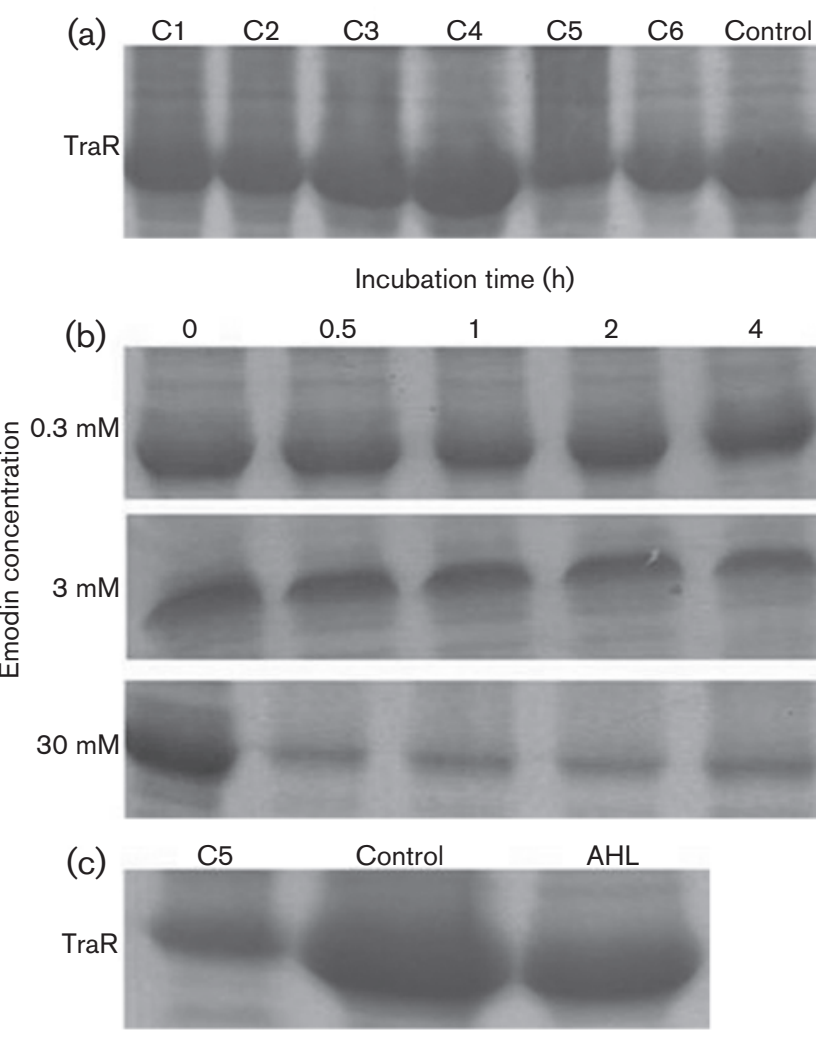

Fig. 4. Effect of different putative OSI compounds on TraR protein degradation in vivo. The $A$. tumefaciens TraR protein was overproduced in E. coli. (a) Cells were treated with different putative QSI compounds. C1-6 (compounds 1-6) at $30 \mathrm{mM}$ or DMSO control for $4 \mathrm{~h}$. (b) Cells treated with emodin (C5) (0.3$30 \mathrm{mM}$ ) for different lengths of time. (c) Cells treated with emodin $(30 \mathrm{mM})$ or DMSO or emodin $(30 \mathrm{mM})$ plus $\mathrm{AHL}\left(10 \mathrm{mg} \mathrm{m}^{-1}\right)$.

QS-deficient $P$. aeruginosa has reduced tolerance to such antimicrobial compounds as tobramycin and $\mathrm{H}_{2} \mathrm{O}_{2}$ (Bjarnsholt et al., 2005; Rasmussen et al., 2005b). In addition, the results also showed that compound 5 can inhibit formation of $S$. maltophilia biofilm (Fig. 3). Interestingly, $S$. maltophilia does not have a traditional AHL-based QS system, as does $P$. aeruginosa (Fouhy et al. 2007), and so if compound 5 specifically targets TraR-like AHL-binding proteins to inhibit biofilm formation, it is not clear how it is able to inhibit biofilm formation in this species. It may be that the role of compound 5 is more of an antibacterial one for S. maltophilia, and so it is more similar to moxifloxacin, which, at concentrations not able to inhibit growth, was able to inhibit the adhesion and biofilm formation of S. maltophilia (Pompilio et al., 2010).

The QS system might be interfered with by decreased AHL biosynthesis, which might be due to decreased AHL transcription that is related to the biosynthase gene mediated by upstream regulators (Yan et al., 2009), degradation of AHL molecules by bacterial lactonases and use of small molecules to block the activation of AHL receptor protein (Rasmussen \& Givskov, 2006). Since the halogenated furanones from $D$. pulchura provided the first examples of QS inhibitors (Givskov et al., 1996), various compounds from fruit, herb and spice extracts have been tested as QS inhibitors (Vattem et al., 2007). In our experiments, compound 5 (emodin) accelerated TraR proteolysis in E. coli (Fig. 4a) and could therefore reduce the concentration of TraR protein in E. coli (Fig. 4b). When the concentration of compound 5 (emodin) increased, the TraR protein was hydrolysed more efficiently, which was consistent with the result reported by Zhu et al. (1998) and Zhu \& Winans (2001). However, TraR proteolysis was inhibited to a certain extent in the presence of the AHL molecule (Fig. 4c), which might be related to a competitive binding of compound 5 and AHL to TraR. In addition, because of the similarities of TraR turnover in both E. coli and A. tumefaciens (Zhu \& Winans, 2001), it is highly probable that these results support a mechanism of action of compound 5 in A. tumefaciens. Because the amino acid residues in the $P$. aeruginosa $\mathrm{QS}$ regulator LasR and $A$. tumefaciens TraR active sites show significant identity (70\%) and the 3D model of the LasR active site closely resembles the X-ray structure of the TraR-active site, the observation that compound 5 (emodin) accelerated TraR proteolysis suggests that it may accelerate LasR proteolysis in $P$. aeruginosa, which would explain its anti-biofilm effects (Müh et al., 2006). The result was consistent with that of halogenated furanones on LuxR protein turnover (Manefield et al., 2002) and that of $P$. aeruginosa on TraR degradation (Zeng et al., 2008). It has also been reported that emodin can inhibit androgen receptor (AR) transcriptional activity, resulting in AR degradation through a proteasome-mediated pathway and suppressing prostate cancer cell growth in vitro (Cha et al., 2005).

In summary, emodin was shown to significantly inhibit biofilm formation in $P$. aeruginosa, and induce proteolysis of a known AHL-binding protein, and could be used as a potential QS inhibitor for the control of biofilm formation and growth.

\section{ACKNOWLEDGEMENTS}

This work was supported by grants from National High-tech R\&D Program of China (863 Program) (2007AA09Z448, 2008AA09Z402), Science and Technology Plan Project of Guangdong (2009B0203 11003), Science and Technology Plan Project of Guangzhou (2008J1C241) and the Central Level, Scientific Research Institutes Special Fund for Basic R \& D (2010TS01). We gratefully thank College of Life Sciences, Sun Yat-Sen University, Guangzhou, PR China for providing the Sybyl 6.9 and thank the Kuntz Group for providing the DOCK program.

\section{REFERENCES}

Adonizio, A. L., Downum, K., Bennett, B. C. \& Mathee, K. (2006). Anti-quorum sensing activity of medicinal plants in southern Florida. J Ethnopharmacol 105, 427-435. 
Basu, S., Ghosh, A. \& Hazra, B. (2005). Evaluation of the antibacterial activity of Ventilago madraspatana Gaertn., Rubia cordifolia Linn. and Lantana camara Linn.: isolation of emodin and physcion as active antibacterial agents. Phytother Res 19, 888-894.

Bergstrom, C. T., Lo, M. \& Lipsitch, M. (2004). Ecological theory suggests that antimicrobial cycling will not reduce antimicrobial resistance in hospitals. Proc Natl Acad Sci U S A 101, 13285-13290.

Bjarnsholt, T., Jensen, P. Ø., Burmølle, M., Hentzer, M., Haagensen, J. A., Hougen, H. P., Calum, H., Madsen, K. G., Moser, C. \& other authors (2005). Pseudomonas aeruginosa tolerance to tobramycin, hydrogen peroxide and polymorphonuclear leukocytes is quorumsensing dependent. Microbiology 151, 373-383.

Bottomley, M. J., Muraglia, E., Bazzo, R. \& Carfi, A. (2007). Molecular insights into quorum sensing in the human pathogen Pseudomonas aeruginosa from the structure of the virulence regulator LasR bound to its autoinducer. J Biol Chem 282, 13592-13600.

Boyen, F., Eeckhaut, V., Van Immerseel, F., Pasmans, F., Ducatelle, R. \& Haesebrouck, F. (2009). Quorum sensing in veterinary pathogens: mechanisms, clinical importance and future perspectives. Vet Microbiol 135, 187-195.

Cha, T. L., Qiu, L., Chen, C. T., Wen, Y. \& Hung, M. C. (2005). Emodin down-regulates androgen receptor and inhibits prostate cancer cell growth. Cancer Res 65, 2287-2295.

Chang, P. C., Li, H. Y., Tang, H. J., Liu, J. W., Wang, J. J. \& Chuang, Y. C. (2007). In vitro synergy of baicalein and gentamicin against vancomycin-resistant Enterococcus. J Microbiol Immunol Infect 40, 5661.

Chen, Q., Zhao, Y., Cheng, Z., Xu, Y. \& Yu, C. (2008). Establishment of a cell-based assay for examining the expression of tumor necrosis factor alpha (TNF- $\alpha$ ) gene. Appl Microbiol Biotechnol 80, 357-363.

Choo, J. H., Rukayadi, Y. \& Hwang, J. K. (2006). Inhibition of bacterial quorum sensing by vanilla extract. Lett Appl Microbiol 42, 637-641.

Costerton, J. W., Lewandowski, Z., DeBeer, D., Caldwell, D., Korber, D. \& James, G. (1994). Biofilms, the customized microniche. J Bacteriol 176, 2137-2142.

Costerton, J. W., Lewandowski, Z., Caldwell, D. E., Korber, D. R. \& Lappin-Scott, H. M. (1995). Microbial biofilms. Annu Rev Microbiol 49, 711-745.

Donlan, R. M. \& Costerton, J. W. (2002). Biofilms: survival mechanisms of clinically relevant microorganisms. Clin Microbiol Rev 15, 167-193.

Drenkard, E. (2003). Antimicrobial resistance of Pseudomonas aeruginosa biofilms. Microbes Infect 5, 1213-1219.

Fouhy, Y., Scanlon, K., Schouest, K., Spillane, C., Crossman, L., Avison, M. B., Ryan, R. P. \& Dow, J. M. (2007). Diffusible signal factordependent cell-cell signaling and virulence in the nosocomial pathogen Stenotrophomonas maltophilia. J Bacteriol 189, 4964-4968.

Frederiksen, B., Koch, C. \& Høiby, N. (1997). Antibiotic treatment of initial colonization with Pseudomonas aeruginosa postpones chronic infection and prevents deterioration of pulmonary function in cystic fibrosis. Pediatr Pulmonol 23, 330-335.

Fu, Z. Y., Han, J. X. \& Huang, H. Y. (2007). Effects of emodin on gene expression profile in small cell lung cancer NCI-H446 cells. Chin Med $J$ (Engl) 120, 1710-1715.

Fujita, M., Shiota, S., Kuroda, T., Hatano, T., Yoshida, T., Mizushima, T. \& Tsuchiya, T. (2005). Remarkable synergies between baicalein and tetracycline, and baicalein and beta-lactams against methicillinresistant Staphylococcus aureus. Microbiol Immunol 49, 391-396.

Fuqua, C. \& Winans, S. C. (1996). Localization of OccR-activated and TraR-activated promoters that express two ABC-type permeases and the traR gene of Ti plasmid pTiR10. Mol Microbiol 20, 1199-1210.
Furci, L. M., Lopes, P., Eakanunkul, S., Zhong, S., Jr, MacKerell, A. D., Jr \& Wilks, A. (2007). Inhibition of the bacterial heme oxygenases from Pseudomonas aeruginosa and Neisseria meningitidis: novel antimicrobial targets. J Med Chem 50, 3804-3813.

Ganin, H., Tang, X. \& Meijler, M. M. (2009). Inhibition of Pseudomonas aeruginosa quorum sensing by AI-2 analogs. Bioorg Med Chem Lett 19, 3941-3944.

Givskov, M., de Nys, R., Manefield, M., Gram, L., Maximilien, R., Eberl, L., Molin, S., Steinberg, P. D. \& Kjelleberg, S. (1996). Eukaryotic interference with homoserine lactone-mediated prokaryotic signalling. J Bacteriol 178, 6618-6622.

Gjødsbøl, K., Christensen, J. J., Karlsmark, T., Jørgensen, B., Klein, B. M. \& Krogfelt, K. A. (2006). Multiple bacterial species reside in chronic wounds: a longitudinal study. Int Wound J 3, 225-231.

Hentzer, M., Wu, H., Andersen, J. B., Riedel, K., Rasmussen, T. B., Bagge, N., Kumar, N., Schembri, M. A., Song, Z. \& other authors (2003). Attenuation of Pseudomonas aeruginosa virulence by quorum sensing inhibitors. EMBO J 22, 3803-3815.

Huang, Y. H. \& Zhen, Y. S. (2001). [Rhein induces apoptosis in cancer cells and shows synergy with mitomycin]. Yao Xue Xue Bao 36, 334338.

Huang, Y., Tsang, S. Y., Yao, X. \& Chen, Z. Y. (2005). Biological properties of baicalein in cardiovascular system. Curr Drug Targets Cardiovasc Haematol Disord 5, 177-184.

Huang, Z. W., Chen, G. C. \& Shi, P. (2008). Emodin-induced apoptosis in human breast cancer BCap-37 cells through the mitochondrial signaling pathway. Arch Pharm Res 31, 742-748.

Jing, Y., Yang, J., Wang, Y., Li, H., Chen, Y., Hu, Q., Shi, G., Tang, X. \& $Y i$, J. (2006). Alteration of subcellular redox equilibrium and the consequent oxidative modification of nuclear factor kappaB are critical for anticancer cytotoxicity by emodin, a reactive oxygen species-producing agent. Free Radic Biol Med 40, 2183-2197.

Jones, S. M., Dang, T. T. \& Martinuzzi, R. (2009). Use of quorum sensing antagonists to deter the formation of crystalline Proteus mirabilis biofilms. Int J Antimicrob Agents 34, 360-364.

Kim, Y. M., Lee, C. H., Kim, H. G. \& Lee, H. S. (2004). Anthraquinones isolated from Cassia tora (Leguminosae) seed show an antifungal property against phytopathogenic fungi. J Agric Food Chem 52, 60966100.

Kwak, H. J., Park, M. J., Park, C. M., Moon, S. I., Yoo, D. H., Lee, H. C., Lee, S. H., Kim, M. S., Lee, H. W. \& other authors (2006). Emodin inhibits vascular endothelial growth factor-A-induced angiogenesis by blocking receptor-2 (KDR/Flk-1) phosphorylation. Int J Cancer 118, 2711-2720.

Lewis, K. (2007). Persister cells, dormancy and infectious disease. Nat Rev Microbiol 5, 48-56.

Lynch, M. J., Swift, S., Kirke, D. F., Keevil, C. W., Dodd, C. E. \& Williams, P. (2002). The regulation of biofilm development by quorum sensing in Aeromonas hydrophila. Environ Microbiol 4, 18-28.

Ma, Z., Otsuyama, K., Liu, S., Abroun, S., Ishikawa, H., Tsuyama, N., Obata, M., Li, F. J., Zheng, X. \& other authors (2005). Baicalein, a component of Scutellaria radix from Huang-Lian-Jie-Du-Tang (HLJDT), leads to suppression of proliferation and induction of apoptosis in human myeloma cells. Blood 105, 3312-3318.

Ma, R., Di, L. Q. \& Xu, H. Q. (2008). Optimization of extraction technology of free anthraquinones from Rheum. Chin Tradit Herb Drugs 39, 858-860.

Manefield, M., de Nys, R., Kumar, N., Read, R., Givskov, M., Steinberg, P. \& Kjelleberg, S. (1999). Evidence that halogenated furanones from Delisea pulchra inhibit acylated homoserine lactone (AHL)-mediated gene expression by displacing the AHL signal from its receptor protein. Microbiology 145, 283-291. 
Manefield, M., Rasmussen, T. B., Henzter, M., Andersen, J. B. Steinberg, P., Kjelleberg, S. \& Givskov, M. (2002). Halogenated furanones inhibit quorum sensing through accelerated LuxR turnover. Microbiology 148, 1119-1127.

Meng, E. C., Gschwend, D. A., Blaney, J. M. \& Kuntz, I. D. (1993). Orientational sampling and rigid-body minimization in molecular docking. Proteins 17, 266-278.

Mittal, R., Sharma, S., Chhibber, S. \& Harjai, K. (2006). Contribution of quorum-sensing systems to virulence of Pseudomonas aeruginosa in an experimental pyelonephritis model. J Microbiol Immunol Infect 39, 302-309.

Müh, U., Hare, B. J., Duerkop, B. A., Schuster, M., Hanzelka, B. L., Heim, R., Olson, E. R. \& Greenberg, E. P. (2006). A structurally unrelated mimic of a Pseudomonas aeruginosa acyl-homoserine lactone quorum-sensing signal. Proc Natl Acad Sci U S A 103, 16948-16952.

Muto, A., Hori, M., Sasaki, Y., Saitoh, A., Yasuda, I., Maekawa, T., Uchida, T., Asakura, K., Nakazato, T. \& other authors (2007). Emodin has a cytotoxic activity against human multiple myeloma as a Janus-activated kinase 2 inhibitor. Mol Cancer Ther 6, 987-994.

Parsek, M. R. \& Greenberg, E. P. (2000). Acyl-homoserine lactone quorum sensing in gram-negative bacteria: a signaling mechanism involved in associations with higher organisms. Proc Natl Acad Sci U S A 97, 8789-8793.

Passador, L., Cook, J. M., Gambello, M. J., Rust, L. \& Iglewski, B. H. (1993). Expression of Pseudomonas aeruginosa virulence genes requires cell-to-cell communication. Science 260, 1127-1130.

Pettersen, E. F., Goddard, T. D., Huang, C. C., Couch, G. S., Greenblatt, D. M., Meng, E. C. \& Ferrin, T. E. (2004). UCSF Chimera a visualization system for exploratory research and analysis. J Comput Chem 25, 1605-1612.

Pompilio, A., Catavitello, C., Picciani, C., Confalone, P., Piccolomini, R., Savini, V., Fiscarelli, E., D’Antonio, D. \& Di Bonaventura, G. (2010). Subinhibitory concentrations of moxifloxacin decrease adhesion and biofilm formation of Stenotrophomonas maltophilia from cystic fibrosis. J Med Microbiol 59, 76-81.

Rasmussen, T. B. \& Givskov, M. (2006). Quorum-sensing inhibitors as anti-pathogenic drugs. Int J Med Microbiol 296, 149-161.

Rasmussen, T. B., Bjarnsholt, T., Skindersoe, M. E., Hentzer, M., Kristoffersen, P., Köte, M., Nielsen, J., Eberl, L. \& Givskov, M. (2005a). Screening for quorum-sensing inhibitors (QSI) by use of a novel genetic system, the QSI selector. J Bacteriol 187, 17991814.

Rasmussen, T. B., Skindersoe, M. E., Bjarnsholt, T., Phipps, R. K., Christensen, K. B., Jensen, P. O., Andersen, J. B., Koch, B., Larsen, T. O. \& other authors (2005b). Identity and effects of quorum-sensing inhibitors produced by Penicillium species. Microbiology 151, 13251340 .
Rumbaugh, K. P., Griswold, J. A. \& Hamood, A. N. (2000). The role of quorum sensing in the in vivo virulence of Pseudomonas aeruginosa. Microbes Infect 2, 1721-1731.

Shih, P. C. \& Huang, C. T. (2002). Effects of quorum-sensing deficiency on Pseudomonas aeruginosa biofilm formation and antibiotic resistance. J Antimicrob Chemother 49, 309-314.

Stover, C. K., Pham, X. Q., Erwin, A. L., Mizoguchi, S. D., Warrener, P., Hickey, M. J., Brinkman, F. S., Hufnagle, W. O., Kowalik, D. J. \& other authors (2000). Complete genome sequence of Pseudomonas aeruginosa PAO1, an opportunistic pathogen. Nature 406, 959-964.

Su, Y. T., Chang, H. L., Shyue, S. K. \& Hsu, S. L. (2005). Emodin induces apoptosis in human lung adenocarcinoma cells through a reactive oxygen species-dependent mitochondrial signaling pathway. Biochem Pharmacol 70, 229-241.

Vannini, A., Volpari, C., Gargioli, C., Muraglia, E., Cortese, R., De Francesco, R., Neddermann, P. \& Marco, S. D. (2002). The crystal structure of the quorum sensing protein TraR bound to its autoinducer and target DNA. EMBO J 21, 4393-4401.

Vattem, D. A., Mihalik, K., Crixell, S. H. \& McLean, R. J. (2007). Dietary phytochemicals as quorum sensing inhibitors. Fitoterapia 78, 302310.

Waters, C. M., Lu, W., Rabinowitz, J. D. \& Bassler, B. L. (2008). Quorum sensing controls biofilm formation in Vibrio cholerae through modulation of cyclic di-GMP levels and repression of $v p s T$. J Bacteriol 190, 2527-2536.

Yan, Q., Wu, X. G., Wei, H. L., Wang, H. M. \& Zhang, L. Q. (2009). Differential control of the PcoI/PcoR quorum-sensing system in Pseudomonas fluorescens 2P24 by sigma factor RpoS and the GacS/ GacA two-component regulatory system. Microbiol Res 164, 18-26.

Yao, Y., Martinez-Yamout, M. A., Dickerson, T. J., Brogan, A. P., Wright, P. E. \& Dyson, H. J. (2006). Structure of the Escherichia coli quorum sensing protein SdiA: activation of the folding switch by acyl homoserine lactones. J Mol Biol 355, 262-273.

You, J. L., Xue, X. L., Cao, L. X., Lu, X., Wang, J., Zhang, L. \& Zhou, S. N. (2007). Inhibition of Vibrio biofilm formation by a marine actinomycete strain A66. Appl Microbiol Biotechnol 76, 1137-1144.

Zeng, Z. R., Qian, L., Cao, L. X., Tan, H., Huang, Y., Xue, X., Shen, Y. \& Zhou, S. (2008). Virtual screening for novel quorum sensing inhibitors to eradicate biofilm formation of Pseudomonas aeruginosa. Appl Microbiol Biotechnol 79, 119-126.

Zhu, J. \& Winans, S. C. (2001). The quorum-sensing transcriptional regulator TraR requires its cognate signaling ligand for protein folding, protease resistance, and dimerization. Proc Natl Acad Sci U S A 98, 1507-1512.

Zhu, J., Beaber, J. W., Moré, M. I., Fuqua, C., Eberhard, A. \& Winans, S. C. (1998). Analogs of the autoinducer 3-oxooctanoyl-homoserine lactone strongly inhibit activity of the TraR protein of Agrobacterium tumefaciens. J Bacteriol 180, 5398-5405. 